Creative Commons User License: CC BY-NC-ND

Abstracted by: EBSCOhost, Electronic Journals Service (EJS)

Google Scholar, Journal Seek, Scientific Commons,

Food and Agricultural Organization (FAO), CABI and Scopus
Journal of Agricultural Extension

Vol. 23 (1) January, 2019

ISSN(e): 24086851; ISSN(Print); 1119944X

http://journal.aesonnigeria.org

http://www.ajol.info/index.php/iae

Email: editorinchief@aesonnigeria.org

\title{
Technological Capabilities of Mill Operators in Palm Oil Processing Enterprise in Anambra State, Nigeria
}

https://dx.doi.org/10.4314/jae.v23i1.8

\section{Ofoka, Innocent Chidike}

Department of Agricultural Extension and Management, Anambra State Polytechnic, Mgbakwu.

E-mail and phone: chykinno@yahoo.com , +2348034077649

\section{Nwalieji, Hyacinth Udeanya}

Department of Agricultural Economics and Extension, Chukwuemeka Odumegwu Ojukwu University (former Anambra State University), Igbariam Campus, Nigeria E-mail: nwalieji73@yahoo.com, hu.nwalieji@coou.edu.ng +2347033994751

\section{Abstract}

The study examined the technological capabilities of mill operators in palm oil processing enterprise in Anambra State. Purposive and simple random sampling techniques were used to select three agricultural zones and a total sample of 48 mill owners/operators, respectively. Data were collected using modified enterprise level interview schedule and analyzed using percentage, mean score and factor analysis. The findings revealed that the majority (87.4\%) of mill operators operated semi-automated oil mill system, had digester (97.9\%), had no capability in terms of investment in equipment (75\%), had no investment capability in human resource development (89.6\%), acquired production (97.9\%) and linkage (95.8\%) capabilities. Lack of manpower $(\bar{x}=3.19)$, market forces $(\bar{x}=$ 3.35), poor remunerations/profit $(\bar{x}=2.69)$, lack of interactions $(\bar{x}=$ 3.42), seasonal scarcity of fruits $(\bar{x}=3.54)$ and lack of fund for business expansion $(\bar{x}=3.56)$ were the constraints to technological capabilities of the mill owners/operators. However, manpower, technical, personnel and infrastructural related factors influenced the development of technological capabilities of mill operators. Extension should liaise with oil palm processors for the dissemination of information on the existing new technologies, tools and knowledge in oil palm processing to minimize the drudgery in oil palm processing.

Keywords: Technological capabilities, palm oil, mill operators

\section{Introduction}

Food and nutrition security remains Africa's most fundamental challenge for human welfare and economic growth. The effectiveness of farmers in producing and processing food is a critical factor in the level of access to food enjoyed by farmers' themselves and the much broader population with whom they are linked via markets. The nature of skills required at all levels for efficient operation in many activities is changing along with technology and organization (Obiora and Madukwe, 2012; Voudouris, Lioukas, latrelli and Caloghirou, 2012). 
Creative Commons User License: CC BY-NC-ND

Abstracted by: EBSCOhost, Electronic Journals Service (EJS)

Google Scholar, Journal Seek, Scientific Commons,

Food and Agricultural Organization (FAO), CABI and Scopus
Journal of Agricultural Extension

Vol. 23 (1) January, 2019

ISSN(e): 24086851; ISSN(Print); 1119944X

http://journal.aesonnigeria.org

http://www.ajol.info/index.php/jae

Email: editorinchief@aesonnigeria.org

There are moves towards a closer integration of science and engineering with production, marketing and managerial know how and changes are also occurring in the relationship between firms, their customers and suppliers, and even their competitors in what is today termed technological capabilities. There is need for a multidimensional, multi-disciplinary and multi-institutional technological capability interaction between actors. Technological capabilities are the skills (technical, managerial or organizational) that enable firms (farms or actors) to efficiently use equipment and information and improve on the technology. Among social scientists, technology includes all tools, machines, utensils, weapons, instruments, housing, clothing, communicating and transporting devices and the skills by which we produce and use them (http:en.wikipedia.org/wiki/technology). Technological capabilities are built through interactions both within the firm (farm) and with external actors. They are the result of interactive learning processes and linkages between a number of actors such as firms, universities and research centers through collaborations both complementary and competing ones (Su, Peng, Shen and Xiao, 2013).

The oil palm processing industry, presents many facets, from traditional labour-intensive activities that are often found in developing countries to the capital-intensive industrial processes common in the industrial world. In order to increase extraction efficiency and increase palm oil production, three types of mechanical processing equipment viz: the screw press, the pioneer mills and hydraulic press which have extraction efficiencies of $66-86 \%$ were first introduced into Nigeria since the 1930s. It includes majorly the processing of the fruits and kernels for oil by the continued efforts of some actors like researchers, fabricators, millers (mill owners) and other processors and the attendant reactions from the consumers of the products (oils) (Sobanke, llori and Adegbite, 2012). Nwalieji and Ojike (2018) noted that the production and processing of oil palm constitute very important sources of employment to many rural dwellers. Until recently the digesting/pounding of parboiled fruit was manually done, using pestles and mortars. However, mechanical, diesel-powered digesters and presses are now found in some processing centres. Also in order to improve extraction efficiency and increase palm oil output, the earlier mentioned machines (screw press, pioneer oil mill and hydraulic press) were complemented with other machines or equipment to achieve continued processing operations mechanically (i.e. starting from introduction of fresh bunch to sterilization-stripper-digester-press-continuous clarifier-oil purifier-oil dryer-oil storage tank). Efforts have been made to disseminate these technologies to processors. The processors use their technological capabilities to exploit, harness and process the oil palm. The mechanical oil palm processing industry is classified into full automated, semi-automated and non-automated operating mills and the technological capabilities of the processors were based on these classifications (Zawislak, Alves, Tello-Gamarra, Barbieux, and Reichert, 2012; Gupta, 2013).

In Anambra State, some oil mills have gone out of business due to poor technological capabilities, some new ones have been established, while others have continued to flourish over the years. The Nigeria Oil Palm Produce Marketing Board (NP-PMB) has played an important role in bringing the quality of Nigeria palm oil up to the standards set in South East Asia (Foundation for Partnership Initiatives in the Niger Delta (PIND), 2011). According to the standards, a grading system was set up as follows: Grade 1 under 9\% Free Fatty Acids (FFA), Grade II -9-18\% FFA, Grade III -18\% to 27\% FFA, Grade IV -27\% -36\% FFA and 
Creative Commons User License: CC BY-NC-ND

Abstracted by: EBSCOhost, Electronic Journals Service (EJS)

Google Scholar, Journal Seek, Scientific Commons,

Food and Agricultural Organization (FAO), CABI and Scopus
Journal of Agricultural Extension

Vol. 23 (1) January, 2019

ISSN(e): 24086851; ISSN(Print); 1119944X

http://journal.aesonnigeria.org

http://www.ajol.info/index.php/iae

Email: editorinchief@aesonnigeria.org

http://eoi.citefactor.org/10.11226/v23i1

Grade V over $36 \%$. The qualities and quantities of oil processed by some fruit processors are acceptable according to the above grading system while those of others are inconsistent and sometimes objectionable with regards to taste, flavour, colour, texture, low quantities and general appearance due to differences in the technological capabilities of the processing enterprises. Also extraction of oil from palm kernel and palm fruits through traditional method has its defects in terms of high labour intensity, only convenient for subsistent small-scale enterprise, inefficient extraction (poor yield) of reasonable quantity of oil from the kernels/palm fruits due to inadequate technological tools etc (The United States Department of Agriculture (USDA), 2017).

However, the need to investigate the technological capabilities of mill operators in palm oil processing for effective and efficient performance becomes imperative. The study therefore sought to examine the technological capabilities of mill operators in palm oil processing enterprise in Anambra State. The specific objectives of the study were to:

i. describe technologies that are available to the processors;

ii. examine technological capabilities of the mill operators; and

iii. identify factors influencing the development of technological capabilities of mill operators.

\section{Methodology}

The study was carried out in Anambra state, Nigeria. Anambra State which lies between latitude $5^{\circ} 4^{1}$ and $7^{\circ} 05^{1}$ North and longitude $6^{\circ} 31^{1}$ and $8^{\circ} 31^{1}$ East occupies an area of approximately $5025 \mathrm{~km}$. The State has an estimated population of 4.18 million people. The climate is characterized by uniformly high temperatures and seasonal distribution of rainfall. The inhabitants of the rural communities are mainly farmers producing staple food crops such as cassava, yam, pear, raffia palm, mangoes, cashew, oil palm, oil bean, African breadfruit, Ogbono, guava etc. The state has four agricultural zones namely; Aguata, Anambra, Awka and Onitsha which are further divided into extension blocks and circles. Also, the inhabitants are engaged in trading and other industrial activities e.g. fabrication of agro-equipment and artisanal workmanships, processing of palm fruits and kernels etc (Nwalieji and Ojike, 2018).

All mechanical oil palm processors in Anambra State constituted the population. The processors were classified into mill operators, mill managers and floor workers according to their functional activities. Based on the concentration of mechanical oil palm processing mills, three agricultural zones were purposively selected as namely; Aguata, Awka and Onitsha. Two extension blocks (EBs) were purposively selected from each selected zone, giving a total of six EBs. Also a purposive selection of four (4) circles in each EB was done to give a total of twenty-four circles selected. Finally, two mill owner/operators were selected in each selected circle using simple random sampling technique to arrive at forty-eight mill owner/operators. The instrument for primary data collection was a modified enterprise level interview schedule that contained structured and semi structured questions. The interview schedule was divided into four sections for the respondents according to objectives.

To identify factors (constraints) that influence the technological capabilities development of the respondents, they were asked to respond to the above possible factors using a four-point Likert type of scale of "to a great extent" (4), "to some extent (3)", to a little extent (2)" and "to no extent (1)". The mean value of 2.5 was used to determine the factors. Variables that have 
Creative Commons User License: CC BY-NC-ND

Abstracted by: EBSCOhost, Electronic Journals Service (EJS)

Google Scholar, Journal Seek, Scientific Commons,

Food and Agricultural Organization (FAO), CABI and Scopus
Journal of Agricultural Extension

Vol. 23 (1) January, 2019

ISSN(e): 24086851; ISSN(Print); 1119944X

http://journal.aesonnigeria.org

http://www.ajol.info/index.php/iae

Email: editorinchief@aesonnigeria.org

a mean value of 2.5 and above were considered as factors that influence technological capability development and those below 2.5 were not. For policy relevance, data were further subjected to exploratory factor analysis procedure using the principal factor model with varimax in grouping the influencing factors. Only variables with loadings of 0.4 and above (10\% overlapping variance) were used in naming the factors.

The data from the study were analyzed with mean scores and factor analysis and the results presented in percentages. Objective one was analyzed using descriptive statistics. Objective two was analyzed using percentage and mean to examine the respondents' technological capabilities. Objective three was analyzed using mean scores and factor analysis. Version 16.0 of the Statistical Product for Service Solution (SPSS) software was used for the analysis.

\section{Results and Discussion \\ Available Technologies to Mill Operators}

Data in Table 1 show that the majority $(87.4 \%)$ of mill operators operated semi-automated oil mill system, $10.4 \%$ operated fully automated oil mill system while $2.2 \%$ of the mill operators operated non-automated milling system. Automated refers to those equipment or machines that are connected to auto-engines to operate. The results show that fully automated milling system starts from steam sterilization- automated digesters - automated press - oil filter (or clarifier tanks) and finally to automated fibre separator. The semi-automated starts from drum cooking of fruits - automated digesters - automated presses - manual oil filtering to manual fibre separation. Non-automated implies that the mechanical screw press and any other equipment are operated manually (see Plates 1\&2).

Entries in Table 1 show that the majority (97.9\%) of the mill operators had digester, $10.4 \%$ had sterilizer, $45.8 \%$ had hydraulic press, 31.3\% had jack press, $22.9 \%$ had manual screw presses while $29.2 \%$ and $2.1 \%$ had fibre separator and stripper respectively. Also, $4.2 \%$, $4.2 \%$ and $4.2 \%$ of the oil mill operators had lift (conveyor), nut cracker and welding plant, respectively. The availability of the above equipment and machines relieve processors of some of their arduous tasks and improve production efficiency and quantity of palm oil produced.

Table 1 reveals that $10.6 \%$ of the mill operators combined sterilizer, digester, hydraulic/jack press and fibre separator (fully automated), $29.8 \%$ of the mill operators combined digester, hydraulic/jack press and fibre separator (semi-automated), 36.2\% of them combined digester and hydraulic press (semi-automated) while $23.4 \%$ of them as well combined digester and hand screw press (semi-automated). The proper combination of equipment is a function of money availability which enhances investments. Some of the processors bought the equipment at the initial stage of the business while some bought as money began to accrue from the business. Fully-automated system is more capital intensive, hence the semiautomated is more acceptable and patronized.

Data in Table 1 also show that the mill operators used different horse-power engines in fully automated mills. It was observed that $4.2 \%$ and $4.2 \%$ of the mill operators used 16 - horse power and 17 horse power engines (diesel), respectively while $2.1 \%$ of the mill operators used 12 horse-power engines to operate fully automated mills. For semi-automated mills, $38.0 \%, 31.3 \%$ and $21.2 \%$ of the mill operators used 12 - horse-power, 10 horse-power and 8 horse-power engines, respectively. Low throughput equipment and machines use low 
Creative Commons User License: CC BY-NC-ND

Abstracted by: EBSCOhost, Electronic Journals Service (EJS),

Google Scholar, Journal Seek, Scientific Commons,

Food and Agricultural Organization (FAO), CABI and Scopus

http://eoi.citefactor.org/10.11226/v23i1
Journal of Agricultural Extension

Vol. 23 (1) January, 2019

ISSN(e): 24086851; ISSN(Print); 1119944X

http://journal.aesonnigeria.org

http://www.ajol.info/index.php/jae

Email: editorinchief@aesonnigeria.org

horsepower engines. The use of low horsepower engines to run high throughput equipment spoils the engines, in a short run, hence it is discouraged.

Table 1: Available technologies

\begin{tabular}{ll}
\hline Available technologies & Percentage $\mathbf{( n = 4 8 )}$ \\
\hline Oil mill system operated: & \\
Fully automated oil mill & 10.4 \\
Semi-automated oil mill & 87.4 \\
Non-automated oil mill & 2.2 \\
Equipment/machine: & \\
Sterilizer & 10.4 \\
Stripper & 2.1 \\
Digester & 97.9 \\
Presses: & \\
Hydraulic press & 45.8 \\
Jack press & 31.5 \\
Handscrew/press & 22.9 \\
Fibre/nut separator & 29.2 \\
Lift (conveyor) & 4.2 \\
Nut cracker & 4.2 \\
Welding machine & 4.2 \\
Combination of equipment/machines: & \\
Sterilizer, digester, hydraulic/Jack press and fibre & separators \\
automated) & 10.6 \\
Digester, hydraulic/Jack press and fibre separator (semi automated) & \\
Digester and hydraulic/Jack press (semi automated) & 29.8 \\
Digester and hand screw press (semi automated) & 36.2 \\
Horse power engine used (diesel): & 23.4 \\
Fully automated mills & \\
12- horse power & \\
16- horse power & 2.1 \\
17- horse power & 4.2 \\
Semi automated mills & 4.2 \\
8 - horse power engine & \\
10 - horse power engine & 21.2 \\
12 - horse power engine & 31.3 \\
\hline Souce:Fid suvey & 38.0 \\
\hline
\end{tabular}

Source: Field survey 
Creative Commons User License: CC BY-NC-ND

Abstracted by: EBSCOhost, Electronic Journals Service (EJS), Google Scholar, Journal Seek, Scientific Commons,

Food and Agricultural Organization (FAO), CABI and Scopus

http://eoi.citefactor.org/10.11226/v23i1

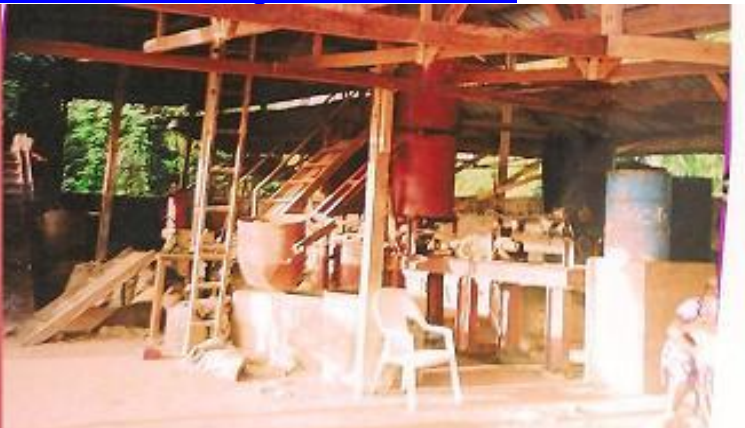

\section{FULLY AUTOMATED OIL MILL METHOD}

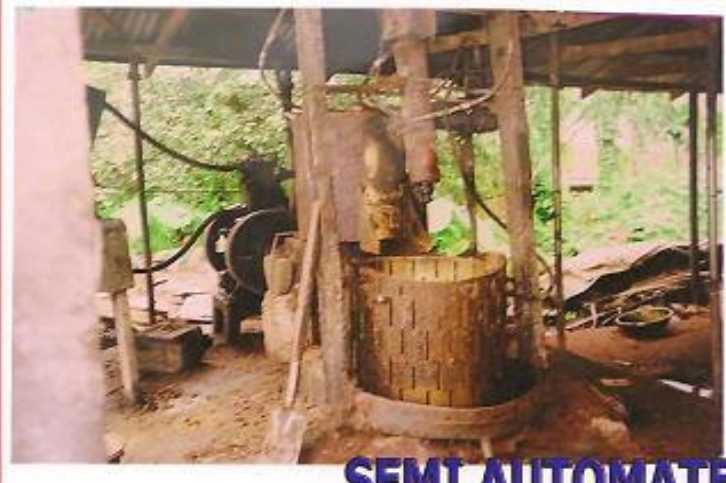

SEMI AUUOMMAIED OIL MILL METHOD
Journal of Agricultural Extension

23 (1) January, 2019

ISSN(e): 24086851; ISSN(Print); 1119944X

http://journal.aesonnigeria.org

http://www.ajol.info/index.php/jae

Email: editorinchief@aesonnigeria.org

Plate 1(a): Fully automated oil mill comprising of sterilizer, digester, press, fibre separator and oil clarification.

(b) Semi automated oil mill comprising cooking drums, digesters, press, manual fibre separation and oil clarification 


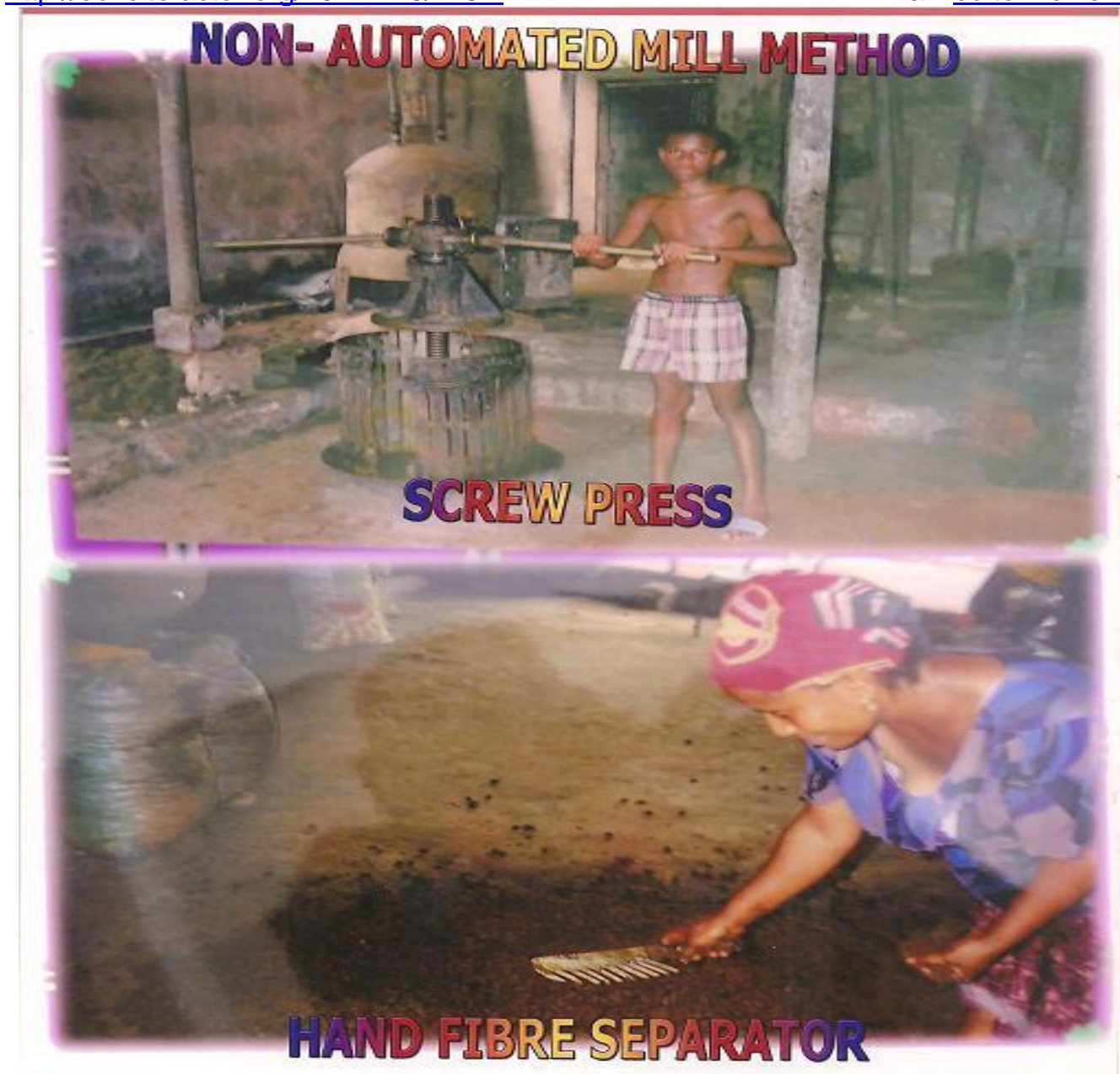

Plate 2: Non-automated oil mill method showing the use of manual screw press and manual fibre separator

\section{Investment Capabilities of Oil Mill Operators}

Figure 1 shows that $75 \%$ of the mill owner/operators claimed they had no capability while $25 \%$ had in terms of investment in equipment. The same figure also shows that $89.6 \%$ had no investment capability while $10.4 \%$ had in human resource development. Investment capabilities are represented by project execution activities including feasibility studies, equipment acquisition, equipment search, employee training etc. Hence investment capability was either investment in machinery (equipment) or human resource development within the last three years of the oil mill establishment. This finding indicates that the majority of the mill owner/operators have little investment capability in terms of both equipment and human resources. This implies that oil mill owner/operators are not adequately disposed in terms of innovation changes or that the investments made so far in terms of equipment and human resources are durable investments that do not need changes often (whether minor or major changes). This result agrees with the findings of Obiora (2012), but is in contrast with the findings of Gourichon (2013) where investment capability was found to be high among the bakery and telecommunications industry, respectively. 
Creative Commons User License: CC BY-NC-ND

Abstracted by: EBSCOhost, Electronic Journals Service (EJS), Google Scholar, Journal Seek, Scientific Commons,

Food and Agricultural Organization (FAO), CABI and Scopus

http://eoi.citefactor.org/10.11226/v23i1
Journal of Agricultural Extension

Vol. 23 (1) January, 2019

ISSN(e): 24086851; ISSN(Print); 1119944X

http://journal.aesonnigeria.org

http://www.ajol.info/index.php/iae

Email: editorinchief@aesonnigeria.org

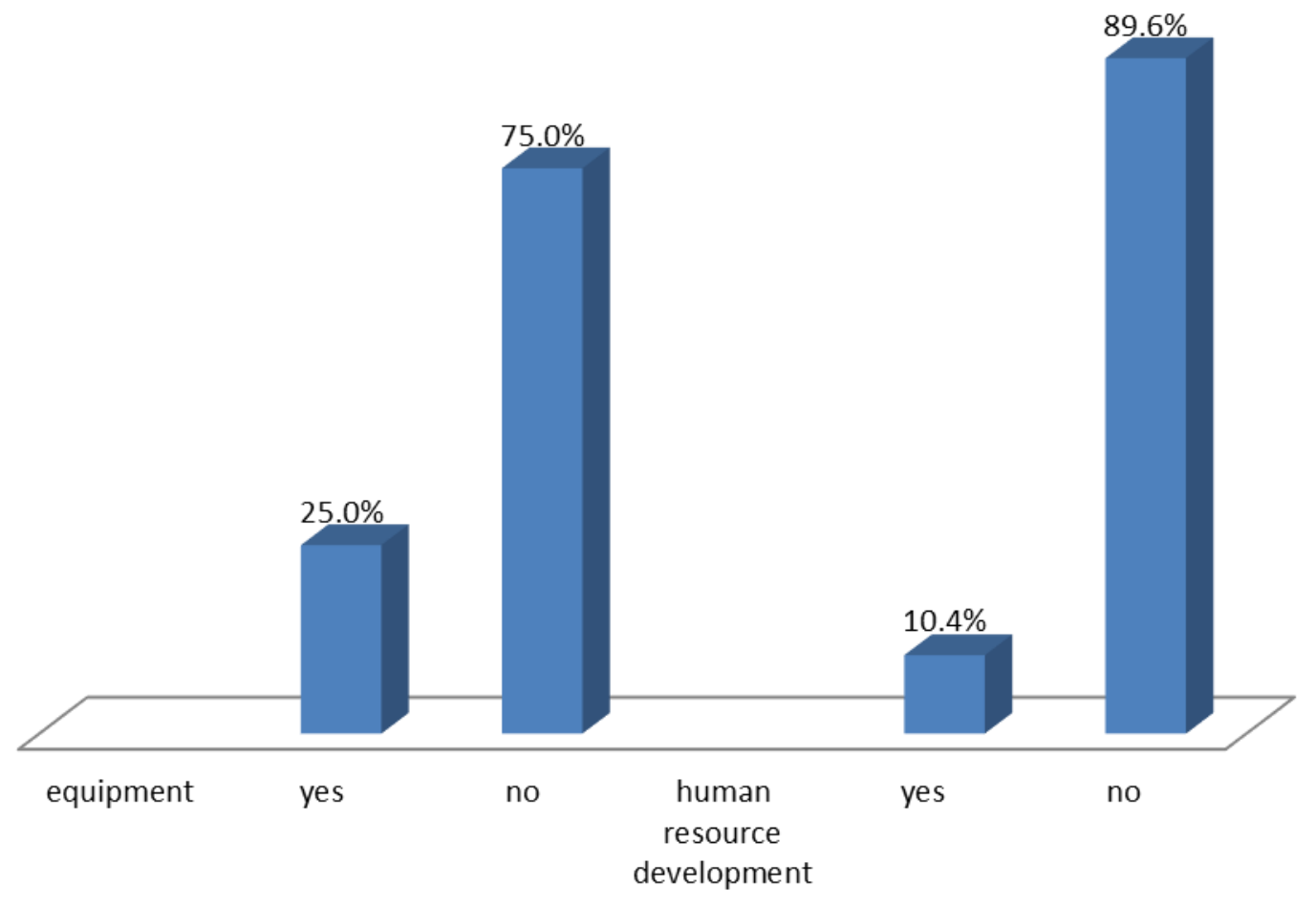

Figure 1: Mill owner/operator that had acquired investment capabilities

Table 2 shows the investment capability (equipment and human resource), which the respondents had acquired. Hundred percent (100\%) of the respondents had acquired digester, 50\% had acquired hydraulic press, $41.7 \%$ had acquired fibre/nut separator, $25.0 \%$ had acquired Jack press, $16.7 \%$ had acquired nutcracker, $16.7 \%$ had acquired welding plant while $25.0 \%$ invested in construction of oil mill house. The result implies that investment within the last three years was done for those equipment needed in the oil mill industry more especially for respondents that changed from non-automated equipment to automated milling equipment. The low investment could also be attributed to long shelf life of processing equipment. The same table equally shows investment in human resource. It shows that $100 \%$ had undergone on-the-job training, which was meant to acquaint them with skilful operating capability of the machines/equipment. 
Creative Commons User License: CC BY-NC-ND

Abstracted by: EBSCOhost, Electronic Journals Service (EJS),

Google Scholar, Journal Seek, Scientific Commons,

Food and Agricultural Organization (FAO), CABI and Scopus

http://eoi.citefactor.org/10.11226/v23i1
Journal of Agricultural Extension

Vol. 23 (1) January, 2019

ISSN(e): 24086851; ISSN(Print); 1119944X

http://journal.aesonnigeria.org

http://www.ajol.info/index.php/iae

Email: editorinchief@aesonnigeria.org

Table 2: Owner/operators investment capability within the last three years

\begin{tabular}{llll}
\hline Equipment capability & $\%{ }^{*}(\mathbf{n}=\mathbf{1 2})$ & Human Resource capability & $\%^{*}(\mathbf{n}=\mathbf{5})$ \\
\hline Type of equipment & 100 & Type of training & 100 \\
Digester & 50.0 & On-the-job training & \\
Hydraulic press & 41.7 & & \\
Fibre/nut separator & 25.0 & \\
Jack press & 16.7 & \\
Nut cracker & 16.7 & & \\
Welding plant & 25.0 & & \\
Construction of mill house & 250
\end{tabular}

${ }^{*}$ Multiple responses

\section{Production Capabilities of Oil Mill Owner/ Operators}

Table 3 shows that $21.3 \%$ of the mills processed between $80-100 \mathrm{~kg}$ of fruits per batch, $10.6 \%$ of them processed $101-150 \mathrm{~kg}$ of fruits, $25.5 \%$ of them processed $151-200 \mathrm{~kg}$ of fruits per batch, $31.9 \%$ of them processed $201-250 \mathrm{~kg}$ of fruits per batch, $10.6 \%$ of them processed between $251-300 \mathrm{~kg}$ of fruits per batch, and $2.2 \%$ of the mills processed above $300 \mathrm{~kg}$ per batch. The result shows varying quantities of fruits processed per batch. This could derive from the different capacities of auto-engines operating the equipment. Engines with low horse-power operated equipment of low capacities while engines of high horsepower operated equipment (for example digester, presses etc.) of high capacities as well. The operators emphasized that use of small auto-engines with big equipment damages the engine very fast.

Table 3: Production capabilities

\begin{tabular}{ll}
\hline Quantity $(\mathbf{K g})$ of fruits processed per batch & Percentage $(\mathbf{n}=\mathbf{4 7})$ \\
\hline $18-100 \mathrm{~kg}$ & 21.3 \\
$101-150 \mathrm{~kg}$ & 10.6 \\
$151-200 \mathrm{~kg}$ & 25.5 \\
$201-250 \mathrm{~kg}$ & 31.9 \\
$251-300 \mathrm{~kg}$ & 10.6 \\
Above $300 \mathrm{~kg}$ & 2.2 \\
\hline
\end{tabular}

\section{Linkage Capabilities of Oil Mill Operators}

Table 4 shows that mill operators $(89.1 \%)$, had direct and vertical linkage with marketers of oil, $100 \%$ had direct/vertical linkage with consumers,73.9\% had horizontal linkage with other fellow mill operators, and $73.9 \%$ had direct linkage with fabricators. This result shows that mill operators had linkage capabilities with actors mentioned above except farmers and extension agents. This could be attributed to commercial nature of service rendered by most oil mill enterprises who do not have direct contact with farmers that produce fruits and sell directly or indirectly to other commercial processors. Also monitoring and evaluation of the activities of oil mill operators in Anambra State by extension agents is yet to be given adequate attention, hence the low linkage of mill operators with extension agents. 
Creative Commons User License: CC BY-NC-ND

Abstracted by: EBSCOhost, Electronic Journals Service (EJS),

Google Scholar, Journal Seek, Scientific Commons,

Food and Agricultural Organization (FAO), CABI and Scopus

http://eoi.citefactor.org/10.11226/v23i1
Journal of Agricultural Extension

Vol. 23 (1) January, 2019

ISSN(e): 24086851; ISSN(Print); 1119944X

http://journal.aesonnigeria.org

http://www.ajol.info/index.php/iae

Email: editorinchief@aesonnigeria.org

Table 4: Linkage capabilities

\begin{tabular}{ll}
\hline Institutional/actors & Percentage $^{\star}(\mathbf{n}=\mathbf{4 6})$ \\
\hline Marketers group & 89.1 \\
Consumers group & 100 \\
Fabricators & 73.9 \\
Other mill operators & 69.5 \\
Extension agents & 6.5 \\
Farmers group & 19.6 \\
\hline
\end{tabular}

\section{${ }^{*}$ Multiple responses}

\section{Factors Influencing the Development of Technological Capabilities of Processors}

Table 5 shows that lack of manpower $(\bar{x}=3.19)$, market forces $(\bar{x}=3.35)$, poor remunerations/profit $(\bar{x}=2.69)$, lack of interactions $(\bar{x}=3.42)$, seasonal scarcity of fruits $(\bar{x}=$ 3.54) and lack of fund for business expansion $(\bar{x}=3.56)$ were the factors that influenced technological capabilities of the mill owner/operators. This implies that if infrastructural facilities are built, workers that move to cities will stay, if there is price control, processors income will not be determined by market forces, hence improving their income to invest more. The issue of seasonal scarcity of palm fruits is a natural influencing factor, hence processors should engage themselves in other businesses during non-peak periods to keep themselves busy. Such businesses may include cracking of kernels, secondary processing of stored palm oil, petty trading, etc.

Table 5: Factors that influence the development of technological capabilities

\begin{tabular}{lll}
\hline Influencing factor & Mean $(\mathbf{n}=\mathbf{4 8})$ & Std. deviation \\
\hline Poor funding for research & 1.73 & 0.765 \\
Poor learning opportunity & 1.98 & 0.565 \\
Lack of manpower & $3.19^{*}$ & 0.610 \\
Unavailability of technology & 1.40 & 0.660 \\
Farm size & 1.23 & 0.444 \\
Bureaucracy/bottleneck of firm & 1.19 & 0.491 \\
Poor government fiscal policy & 2.15 & 0.875 \\
Market forces & $3.35^{\star}$ & 0.483 \\
Poor remunerations/profits & $2.69^{*}$ & 0.512 \\
Lack of interaction among actors & $3.42^{*}$ & 0.613 \\
Lack of legal frame work & 1.54 & 0.771 \\
Poor access to knowledge & 1.48 & 0.714 \\
Poor infrastructure & 2.29 & 0.824 \\
Seasonal scarcity of palm fruits & $3.54^{*}$ & 0.683 \\
Lack of fund for the expansion & $3.56^{*}$ & 0.616 \\
\hline
\end{tabular}

\section{* Significant influencing factors}


Creative Commons User License: CC BY-NC-ND

Abstracted by: EBSCOhost, Electronic Journals Service (EJS)

Google Scholar, Journal Seek, Scientific Commons,

Food and Agricultural Organization (FAO), CABI and Scopus
Journal of Agricultural Extension

Vol. 23 (1) January, 2019

ISSN(e): 24086851; ISSN(Print); 1119944X

http://journal.aesonnigeria.org

http://www.ajol.info/index.php/jae

Email: editorinchief@aesonnigeria.org

\section{Factors Influencing the Development of Technological Capabilities of Mill Operators}

Data in Table 6 show variable loading factors as viz factor $1=$ manpower; factor $2=$ technical problems; factor 3 = personnel problems and factor $4=$ infrastructural problems. Entries in the same Table show that factors that loaded under manpower problem (Factor 1) were lack of manpower (0.663), poor government fiscal policy $(0.428)$, seasonal scarcity of palm fruits (0.580) and poor fund for business expansion (0.675). Lack of skilled manpower has been identified as important factor for the low level of technological capability development in many firms in developing countries (Haeussler, Patzelt and Zahra, 2012). Inadequate funding will not allow actors to invest in business expansion, training and development or state of the art technology acquisition. Also poor funding will not allow business diversifications to cushion the effects of seasonal scarcity of palm fruits during some months of the year (July January).

Farm size (0.683), poor remunerations/profits (0.427) and knowledge (0.757) loaded high under technical factors (Factor 2) (Table 6). Poor remuneration means financial handicap, hence limiting the ability to invest in or access knowledge which also affects negatively the firms' size in the long run retarding the technological capabilities of the mill operators.

Factor 3 has to do with loadings of poor learning opportunities $(-0.659)$ and lack of interactions among actors (-0.537). Interactions between actors will allow them swap information and enhance learning (Molina-Domene and Pietrobelli, 2012; Obiora and Madukwe, 2012). Such learning will permit the actors to accumulate technological capability in mechanical oil palm fruits processing industry. Lack of interaction hence implies that there will be no opportunity of learning and development of technological capabilities of the mill operators.

Factor four on infrastructural problems were dominated by poor infrastructure (0.739) and firm's poor organizational structures (0.612). According to FAO (2013) a good marketing infrastructure, maintenance of rural roads, supply of water, and marketing services have profound effects on food availability, market prices and physical access to food at the community level. Conversely, poor marketing infrastructure, particularly price fluctuations etc. limit the investment and production capabilities of the actors/processors. 
Creative Commons User License: CC BY-NC-ND

Abstracted by: EBSCOhost, Electronic Journals Service (EJS),

Google Scholar, Journal Seek, Scientific Commons,

Food and Agricultural Organization (FAO), CABI and Scopus

http://eoi.citefactor.org/10.11226/v23i1
Journal of Agricultural Extension

Vol. 23 (1) January, 2019

ISSN(e): 24086851; ISSN(Print); 1119944X

http://journal.aesonnigeria.org

http://www.ajol.info/index.php/iae

Email: editorinchief@aesonnigeria.org

Table 6: Factors that influence the development of technological capabilities of oil mill operators

\begin{tabular}{|c|c|c|c|c|}
\hline Influencing factors & $\begin{array}{l}\text { Rotated con } \\
\text { Factor } 1 \\
\text { Manpower } \\
\text { related }\end{array}$ & $\begin{array}{l}\text { nponent ma } \\
\text { Factor } 2 \\
\text { Technical } \\
\text { related }\end{array}$ & $\begin{array}{l}\text { trix } \\
\text { Factor } 3 \\
\text { Personnelrelated }\end{array}$ & $\begin{array}{l}\text { Factor } 4 \\
\text { Infrastructure } \\
\text { related }\end{array}$ \\
\hline $\begin{array}{l}\text { Poor funding for } \\
\text { research }\end{array}$ & -0.376 & -0.063 & -0.077 & -0.032 \\
\hline $\begin{array}{ll}\text { Poor } & \text { learning } \\
\text { opportunities } & \end{array}$ & 0.197 & 0.006 & -0.659 & -0.355 \\
\hline Lack of manpower & 0.663 & 0.116 & -0.053 & 0.115 \\
\hline $\begin{array}{l}\text { Unavailability } \\
\text { technology }\end{array}$ & -0.224 & -0.218 & -0.192 & 0.187 \\
\hline Farm size & 0.260 & 0.680 & 0.039 & -0.017 \\
\hline Bureaucracy & 0.140 & 0.446 & 0.013 & 0.711 \\
\hline $\begin{array}{l}\text { Firm's organizational } \\
\text { Structure }\end{array}$ & -0.031 & -0.254 & 0.016 & 0.612 \\
\hline $\begin{array}{l}\text { Poor government fiscal } \\
\text { policy }\end{array}$ & 0.428 & 0.098 & 0.777 & -0.032 \\
\hline Market forces & 0.510 & 0.110 & 0.709 & -0.070 \\
\hline $\begin{array}{l}\text { Poor } \\
\text { remunerations/profits }\end{array}$ & 0.346 & 0.427 & 0.186 & 0.073 \\
\hline $\begin{array}{l}\text { Lack of interaction } \\
\text { among actors }\end{array}$ & 0.174 & -0.024 & -0.537 & 0.022 \\
\hline Lack of legal framework & 0.258 & -0.628 & 0.202 & 0.417 \\
\hline $\begin{array}{l}\text { Poor access to } \\
\text { knowledge }\end{array}$ & -0.009 & 0.757 & 0.110 & 0.203 \\
\hline Poor infrastructure & 0.045 & 0.128 & 0.040 & 0.739 \\
\hline $\begin{array}{l}\text { Seasonal scarcity of } \\
\text { palm fruits }\end{array}$ & 0.580 & 0.172 & -0.155 & 0.106 \\
\hline $\begin{array}{l}\text { Poor fund for business } \\
\text { expansion }\end{array}$ & 0.675 & -0.172 & 0.074 & -0.195 \\
\hline
\end{tabular}

Extraction method: principal component analysis

Rotation method: Varimax with Kaiser Normalization (Loading at .4 and above)

\section{Conclusion and Recommendations}

Factors that influenced the development of the operators' technological capabilities included manpower, technical, personnel and infrastructural related factors; lack of manpower, market forces, poor remunerations/profit, lack of interactions, seasonal scarcity of fruits and inadequate fund for business expansion.

Extension organizations should form linkages between oil palm processing enterprises and other agencies such as research and technology transfer groups like ADP, Ministry of 
Creative Commons User License: CC BY-NC-ND

Abstracted by: EBSCOhost, Electronic Journals Service (EJS)

Google Scholar, Journal Seek, Scientific Commons,

Food and Agricultural Organization (FAO), CABI and Scopus
Journal of Agricultural Extension

Vol. 23 (1) January, 2019

ISSN(e): 24086851; ISSN(Print); 1119944X

http://journal.aesonnigeria.org

http://www.ajol.info/index.php/jae

Email: editorinchief@aesonnigeria.org

Agriculture etc. that make input into the enterprises and the consumers of the output from the oil palm processing enterprises. Extension in addition, should co-ordinate the activities of all the stakeholders in the oil palm processing industry in areas of policy formulation and implementation and should sensitize government to support the industry through appropriate fiscal measures such as grants, loans, tax relief and subsidies. Extension should liaise with oil palm processors for dissemination of information about the existing new technologies, tools and knowledge in oil palm processing which the processors had been responding tacitly to their existence and availability. Hence the drudgery in oil palm processing will be highly minimized.

\section{References}

Food and Agriculture Organization of the United Nations (FAO) (2013). Small-scale palm oil processing in Africa. Agricultural Services Bulletin 148. Rome, Itally.

Foundation for Partnership Initiatives in the Niger Delta (PIND) (2011). A report on palm oil value chain analysis in the Niger Delta. 167 Ademola Adetokunbo Crescent, Wuse II, Abuja, Nigeria

Gourichon, H. (2013). Analysis of incentives and disincentives for palm oil in Nigeria. Technical Notes Series, MAFAP, FAO, Rome. http://www.fao.org/mafap. retrieved 09/03/15.

Gupta, R. (2013). Reactivating Nigeria's oil palm industry. Retrieved on 26/01/18 from http://businessdayonline.com/2013/06/reactivating-nigerias-oil-palmindustry-3/

Haeussler, C., Patzelt, H. \& Zahra, S. A. (2012). Strategic alliances and product development in high technology new firms: The moderating effect of technological capabilities. Journal of Business Venturing, 27 (1), 217-233.

http:en.wikipedia.org/wiki/technology. Retrieved on 26/09/2018.

Molina-Domene, M. A. \& Pietrobelli, C. (2012). Drivers of technological capabilities in developing countries: an econometric analysis of Argentina, Brazil and Chile. Journal of Structural Change and Economic Dynamics, 23(1), 504- 515.

Nwalieji, H.U. \& Ojike, H.U. (2018). Characteristics of Small-Scale Palm Oil Production Enterprise in Anambra State. Journal of Agricultural Extension, 22 (1) February, 2234.

Obiora, C. J. (2012). Technological capabilities of climate change actors in the agricultural innovation system of South East, Nigeria. A Ph.D. Thesis, Department of Agricultural Extension, University of Nigeria, Nsukka, pp. 66 -68.

Obiora, C., \& Madukwe, M. (2012). Provisions for climate change technological capability in the agricultural policies, acts and initiatives in Nigeria. Journal of Agricultural Extension, 16(2), 46-57.

Sobanke, V., Ilori, M. \& Adegbite, S. (2012). Technological Capability in Metal Fabricating Firms in Southwestern Nigeria. American Journal of Industrial and Business Management, 2(4), 176-183 
Creative Commons User License: CC BY-NC-ND

Abstracted by: EBSCOhost, Electronic Journals Service (EJS)

Google Scholar, Journal Seek, Scientific Commons,

Food and Agricultural Organization (FAO), CABI and Scopus

http://eoi.citefactor.org/10.11226/v23i1
Journal of Agricultural Extension

Vol. 23 (1) January, 2019

ISSN(e): 24086851; ISSN(Print); $1119944 X$

http://journal.aesonnigeria.org

http://www.ajol.info/index.php/iae

Email: editorinchief@aesonnigeria.org

Su, Z., Peng, J., Shen, H. \& Xiao,T. (2013). Technological capability, marketing capability, and firm performance in turbulent conditions. Journal of Management and Organization Review, 9 (1), 115-137.

The United States Department of Agriculture (USDA) (2017). Nigeria palm oil production by year 1964-2017 (1000 MT). Retrieved on 22/08/18 from http://www.usda.gov/

Voudouris, I., Lioukas, S., latrelli, M. \& Caloghirou, Y. (2012). Effectiveness of technology investment: impact of internal technological capability, networking and investment's strategic importance. Journal of Technovation, 32 (1), 400-414.

Zawislak, P., Alves, A., Tello-Gamarra, J., Barbieux, D. \& Reichert, F. (2012). Innovation capability: from technology development to transaction capability. Journal of Technology Management and Innovation, 7(2), 14-27. 